\title{
PENGARUH KEPEMIMPINAN, BUDAYA ORGANISASI DAN MOTIVASI TERHADAP KINERJA PEGAWAI UPT DINAS PENDIDIKAN, PEMUDA DAN OLAHRAGA KABUPATEN BIREUEN
}

\author{
Asralidin ${ }^{1)}$ dan Zainudin Iba ${ }^{2 *}$ \\ 1 Sekretaris Dinas Pendidikan dan Kebudayaan Kabupaten Bireuen \\ 2, Dosen FE Universitas Islam kebangsaan Indonesia (UNIKI) \\ *) email: zainuddin.iba@uniki.ac.id
}

DOI:

https://doi.org/10.55178/idm.v2i4.221

ABSTRACT

Article history

Received:

September 11, 2021

Revised:

September 16, 2021

Accepted:

September 20, 2021

Page:

$37-45$

Kata kunci:

Leadership,

organizational culture, motivation, employee performance
This study aims to examine, 1) the influence of leadership on employee performance, 2) the influence of organizational culture on employee performance, 3) the influence of motivation on employee performance, and 4) the influence of leadership, organizational culture and motivation on the performance of UPT employees of the Department of Education, Youth and Bireuen Regency Sports. The research method used in this study is the associative method with a quantitative approach, to 104 employees, with the collection technique using a closed questionnaire instrument. The analytical method used is a path analysis approach. The results of the study show that 1) There is a significant influence of leadership factors on employee performance. Statistically, with a large influence of 19.74 percent on the performance of the employees of UPTD Education, Youth and Sports, Bireuen Regency. 2) It is proven that there is an influence of organizational culture on employee performance by 19.46 percent, 3) It is found that there is a significant influence of work motivation factors of 12.81 percent on the performance of UPTD Youth and Sports Education, Bireuen Regency. The relationship between leadership factors, organizational culture and motivation on employee performance has a high closeness, and is linearly related, with a degree of relationship of 0.721 . And the contribution of leadership factors, organizational culture and motivation to the performance of the employees of the UPTD Youth and Sports Education in Bireuen Regency is 52\%. While the rest of the role of variables that are not examined by 48\%. This shows that there are other factors that can influence employee performance variables, such as organizational climate, career development factors, education and training, and others.

\section{Pendahuluan (Introduction)}

Hasil kinerja pegawai pada Unit pelaksana Teknis (UPT) Dinas Pendidikan, Pemuda dan Olahraga Kabupaten Bireun belum menggembirakan. Hasil perhitungan sasaran kinerja pegawai tahun 2020 lalu, rerata baru mencapai 82,5 dan masih terdapat sekitar 15 persen dengan kategori sedang dan cukup yakni dibawah 75 .

Tentunya, hal ini harus menjadi perhatian pimpinan UPT, agar apa yang menjadi target dan harapan dalam menunjang hasil kerja perlu ditingkatkan. Salah satu yang ikut memberi andil adanya kepemimpinan yang mampu menggerakkan bawahannya untuk bekerja tekun sesuai tupoksi dan memiliki semangat berprestasi.

Karena apa yang telah diperbut di lingkungan UPT Dinas ini, seperti telah mengupayakan agar pegawai dapat melaksanakan tugas dan fugsinya dengan baik. Antarannya adalah melalui pemberian dana tunjangan prestasi kerja, pemenuhan sarana dan prasarana sehingga tujuan yang ingin dicapai dapat terwujud. Ternyata belum berarti baik dalam hasil kinerjanya. 
Keberhasilan pembangunan bidang pendidikan dan kepemudaan di daerah yang diamanahkan pada UPT Dinas ini, akan dapat terlaksana dengan optimal, manakala Sumber Daya Manusia (SDM) mendukung. Dan peran pemimpin dalam mengelola SDM sangat menentukan.

Realitasnya, kinerja pegawai di UPT Dinas Pendidikan, Pemuda dan Olahraga Kabupaten Bireuen masih jauh dari yang diharapkan. Terkadang tampak adanya Pegawai yang kurang memahami tugas pokok dan fungsinya. Juga kemampuan penggunaan teknologi yang lemah berdampak pada pelayanan yang tidak prima dalam urusan administrasi misalnya. Ditambah lagi dengan adanya sebagian pegawai yang tidak mau meningkatkan kualitas dirinya sehingga dapat bekerja lebih optimal.

Pentingnya pemimpin menjalankan tugas dan fungsi manajemen, tidak bisa ditunda dalam meningkatkan kewibawaan unit kerja atau institusi, apalagi unit yang diamanahkan untuk mengelola bidang pendidikan, dan kepemudaan. Maka pemimpin yang baik, haruslah memiliki visi luas, mempunyai konsep yang jelas dan mengerti benar kebutuhan organisasi diharapkan akan berhasil dalam memimpin organisasi.

Di lain pihak juga adanya dukungan dari budaya organisasi akan mampu menumbuhkan semangat bekerja lebih baik, karena di dalamnya ada kesepakatan yang dipahami dan dikerjakan, terdapat nilai-nilai yang dipertahankan dan diturunkan kepada setiap pegawai baik baru atau pun yang sudah lama.

Disamping itu, kepatuhan pegawai akan tugas kewajiban yang ditandai dengan motivasi kerja yang tinggi dari pegawai dalam mengemban tugas sesuatu yang menjadi keniscayaan. Karena penurunan kinerja pegawai sering terjadi selaras dengan menurunnya motivasi kerja para pegawai. Sutrisno (2013:109) mengemukakan motivasi adalah "faktor yang mendorong seseorang untuk melakukan suatu aktivitas tertentu, motivasi sering kali diartikan pula sebagai faktor pendorong perilaku seseorang”. Mangkunegara (2012:61) juga mengemukakan motivasi adalah "kondisi atau energi yang menggerakkan diri pegawai yang terarah atau tertuju untuk mencapai tujuan organisasi”.

Ketiga faktor diatas, menjadi hasrat peneliti untuk meninjau dan melakukan umpan balik dalam membuktikan pengaruhnya atas factor kinerja pegawai.

\section{Tinjauan Literatur (Literature Review)}

\section{Pengaruh Kepemimpinan terhadap Kinerja Pegawai}

Widjaya (2010:27) menyatakan bahwa Pemimpin mempunyai tugas utama untuk mengetahui pengaruh mana yang dapat mendorong orang-orang yang dipimpin agar bersedia bertindak untuk mencapai tujuan yang telah ditetapkan sebelumnya. Apabila mengetahui pengaruh-pengaruh itu, maka para pemimpin itu dapat menerapkannya pada orang-orang yang dipimpinnya atau pengikutnya, sebab salah satu tugas pokok seorang pemimpin adalah menggerakkan orang-orang yang dipimpinnya untuk mencapai tujuan organisasi.

Thoha (2010:52), mengungkap kepemimpinan dapat dilihat dari fungsi kepemimpinan dalam hubungannya dengan peningkatan aktivitas dan efisiensi organisasi, yaitu: 1) Fungsi kepemimpinan sebagai inovator, 2) Fungsi kepemimpinan sebagai komunikator, 3) Fungsi kepemimpinan sebagai motivator, dan 4) Fungsi kepemimpinan sebagai kontroler.

Faktor kepemimpinan yang efektif akan berpengafruh positif terhadap kinerja bawahan (Siagian, 2006:66).

\section{Pengaruh Budaya Organisasi terhadap Kinerja Pegawai}

Unit Pelaksana Teknik sebagai perpanjangan tangan dari Dinas memiliki Budaya organisasi yang diatur dalam undang-undang dan peraturan pemerintah. Sebagai institusi pemerintah, budaya diciptakan selain sebagai ciri juga merupakan bentuk perilaku pegawai dalam bekerja. Perilaku pegawai yang sesuai dengan budaya organisasi tersebut akan memberikan dampak pada kinerja pegawai. Sehingga Budaya organisasi menjadi salah satu kriteria penting dalam menentukan pertumbuhan dan keberhasilan suatu organisasi.

Moeheriono (2012:336) mengartikan budaya organisasi sebagai pola keyakinan dan nilai-nilai (values) organisasi yang dipahami, dijiwai, dan dipraktikkan oleh organisasi sehingga pola tersebut memberikan arti tersendiri dan menjadi dasar aturan berperilaku dalam organisasi.

Budaya pada hakekatnya merupakan pondasi bagi suatu organisasi. Jika pondasi yang dibuat tidak cukup kokoh, maka betapapun bagusnya suatu bangunan, ia tidak akan cukup kokoh untuk menopangnya. Menurut Robbins (2015) karakteristik utama dalam budaya organisasi, yaitu: 1) Inisiatif individual. Yang terkait dengan tingkat tanggung jawab, kebebasan, dan independensi yang dipunyai individu. 2) Toleransi terhadap tindakan beresiko. Sejauh mana para pegawai dianjurkan untuk bertindak agresif, inovatif, dan mengambil resiko. 3) Arah, yakni sejauh mana organisasi tersebut menciptakan dengan jelas sasaran dan 
hararapan mengenai prestasi. 4) Integrasi, yakni tingkat sejauh mana unit-unit dalam organisasi didorong untuk bekerja dengan cara yang terkoordinasi dengan baik, 5) Dukungan dari manajemen, 6) Adanya Kontrol dalam penerapan peraturan dan pengawasan serta pengendalian perilaku pegawai. Juga yang tak kalah 7) Toleransi terhadap konflik serta 8) Pola-pola komunikasi yang diciptkan.

\section{Pengaruh Motivasi terhadap Kinerja Pegawai}

Motivasi seseorang melakukan pekerjaan karena memiliki tujuan untuk memenuhi kebutuhan hidupnya. Seseorang akan merasakan kekhawatiran apabila kebutuhan hidupnya tidak tercapai sehingga hal tersebut akan mempengaruhi dalam diri individu untuk lebih meningkatkan motivasinya (Robbins, 2010).

Unit pelaksana Teknis sebagai Organisasi, harus memperhatikan bagaimana mengelola dan menjaga motivasi pegawai dalam bekerja supaya terus bersemangat dan fokus pada tujuan yang akan dicapai, sesuai visi dan misi. Menjaga motivasi pegawai sama hal nya menjaga dan mendorong pegawai melakukan dan mengerjakan sesuatu secara tertib dan terukur. Seseorang tidak akan mengerjakan suatu hal secara maksimal apabila tidak memiliki dorongan dan motivasi yang tinggi dalam dirinya sendiri. Dengan adanya motivasi yang tepat maka karyawan akan terdorong untuk berbuat semaksimal mungkin dalam melaksanakan tugasnya. Motivasi pegawai yang tinggi akan menciptakan sebuah komitmen terhadap tanggung jawabnya dalam setiap pekerjaan (Mustika, 2016).

Vroom dalam Winardi (2010:238) menyatakan adanya hubungan motivasi kerja terhadap kinerja yaitu: "bahwa seseorang pegawai akan bersedia melakukan upaya yang lebih besar apabila diyakini bahwa upaya itu akan berakibat pada penilaian kinerja yang baik dan bahwa penilaian kinerja yang baik akan dan bahwa penilaian kinerja dan kesemuanya itu memungkinkan yang bersangkutan untuk mencapai tujuan pribadinya".

\section{Metode Penelitian (Methodology)}

\section{a. Metode dan Variabel Penelitian}

Metode penetian yang akan digunakan dalam penelitian ini adalah metode asosiatif dengan pendekatan kuantitatif. Metode asosiatif merupakan metode yang bermaksud untuk menjelaskan hubungan kausal dan pengaruh antara variabel-variabel melalui pengujian hipotesis.

Penelitian dilakukan pada kantor UPT Dinas Pendidikan, Pemuda dan Olahraga Kabupaten Bireuen, terhadap 105 pegawai yang berstatus PNS. Dalam rangka mnemperoleh data, maka terhadap pegawai di berikan angket atau kuesioner berkaitan dengan variable yang diteliti, menggunakan angket tertitip dengan skala linert-5. Sehingga responden hanya menjawab persepsi mereka tentang pernyataan tentang variabel Kepemimpinan, Budaya organisasi, motivasi pegawai dan menulis nilai yang diperpleh dari sasaran kinerja pegawai sebagai ukuran tingkat kinerja.

Adapun variabel, dimensi dan indikator pengukur setiap variabelnya dinyatakan berikut ini.

Tabel 1. Operasional Variabel Penelitian

\begin{tabular}{|c|c|}
\hline Variabel & Dimensi \\
\hline $\begin{array}{c}\text { Kepemimpinan } \\
\qquad\left(\mathrm{X}_{1}\right) \\
\text { Sumber: Toha }(2010: 21)\end{array}$ & $\begin{array}{l}\text { 1. Fungsi kepemimpinan sebagai inovator } \\
\text { 2. Fungsi kepemimpinan sebagai komunikator } \\
\text { 3. Fungsi kepemimpinan sebagai motivator } \\
\text { 4. Fungsi kepemimpinan sebagai kontroler }\end{array}$ \\
\hline $\begin{array}{c}\text { Budaya organisasi } \\
\text { (X2) } \\
\text { Sumber: Robbins dan Timoty } \\
(2008: 256)\end{array}$ & $\begin{array}{l}\text { 1. Kesadaran diri } \\
\text { 2. Keagresifan } \\
\text { 3. Kepribadian } \\
\text { 4. Performa } \\
\text { 5. Orientasi tim }\end{array}$ \\
\hline $\begin{array}{c}\text { Motivasi kerja } \\
\text { (X3) } \\
\text { Sumber: Hasibuan (2013:143) }\end{array}$ & $\begin{array}{l}\text { 1. Kebutuhan akan prestasi } \\
\text { 2. Kebutuhan akan afiliasi } \\
\text { 3. Kebutuhan akan kekuasaan }\end{array}$ \\
\hline $\begin{array}{c}\text { Kinerja } \\
(\mathrm{Y}) \\
\text { Sumber: Wibowo (2011:7). }\end{array}$ & $\begin{array}{ll}\text { 1. Kuantitas., } & \text { 2. Kualitas } \\
\text { 3. Waktu, } & \text { 4. Biaya } \\
\text { 5. Orientasi Pelayanan, } & \text { 6. Integritas } \\
\text { 7. Komitmen, } & \text { 8. Disiplin } \\
\text { 9. Kerjasama, } & \text { 10. Kepemimpinan }\end{array}$ \\
\hline
\end{tabular}




\section{b. Alat Analisis}

Alat analisi diterapkan dengan statistik parametrik, maka langkah awal adalah melakukan transformasi data angket yang berskala ordinal menjadi skala interval, dengan metode sussesiv interval. Alat analisis masalah dan menjawab tujuan penelitian, dilakukan dengan model analisis jalur, karena antar variabel bebas adanya hubungan kausalitas.

Analisis jalur ialah suatu teknik untuk menganalisis hubungan sebab-akibat yang terjadi pada regresi berganda jika variabel bebasnya mempengaruhi variabel tergantungnya tidak hanya secara langsung, tetapi juga secara tidak langsung” (Robert D. Rutherford, 1993, dalam Marwan Hamid, dkk; 2019:10).

Analisis jalur memungkinkan pengguna dapat menguji proposisi teoritis mengenai hubungan sebab dan akibat tanpa memanipulasi variabel-variabel (Sarwono, 2011).

Untuk dapat menggunakan alat analisis ini, juga menuntut jaminan atau syarat statistik parametrik yakni terpenuhinya semua asumsi klasik, yaitu asumsi normalitas, heterosidasitas, multikolinieritas dan autokorelasi.

\section{Hasil dan Pembahasan (Results and Discussion)}

\section{a. Pemeriksaan Validitas Butir Pernyataan dalam Instrumen Penelitian}

\section{Uji Valisitas Variabel Kepemimpinan $\left(X_{1}\right)$}

Sesuai dengan konsep operasional penelitian ini, Instrumen yang mengukur variabel Kepemimpinan $\left(\mathrm{X}_{1}\right)$ berdasarkan 4 dimensi, yakni Fungsi kepemimpinan sebagai 1) inovator, 2) komunikator, 3) motivator, dan 4) kontroler.

Dengan menggunakan rumus korelasi rank-Spearmann, kemudian hasilnya dikonsultasikan pada $r_{\text {tabel }}$ dengan taraf signifikan $\alpha=0,05$. Untuk menghitung nilai $r$-hitung, setelah semua butir angket diberikan bobot, peneliti menghitung koefisien korelasinya skor setiap item dengan skor total variabel $\mathrm{X}_{1}$. Maka diperoleh hasil perhitungan korelasi setiap butir dengan total skor variabel ini sebagaimana dinyatakan dalam tabel 2 berikut:

Tabel 2. Uji Validitas Instrumen untuk Variabel Kepemimpinan $\left(\mathrm{X}_{1}\right)$

\begin{tabular}{|c|l|c|c|c|c|}
\hline Butir & \multicolumn{1}{|c|}{ Pernyataan tentang } & r-hitung & r-tabel $(\alpha=5 \%)$ & Sig & Keputusan \\
\hline 1 & Pimpinan memiliki kemampuan berkomunikasi & 0.489 & 0.195 & 0,000 & Valid \\
\hline 2 & Pimpinan menyampaikan ide/gagasan kreatif & 0.487 & 0.195 & 0,000 & Valid \\
\hline 3 & Pimpinan bisa menyelesaikan masalah & 0.528 & 0.195 & 0,000 & Valid \\
\hline 4 & Pimpinan mempunyai konsep kerja yang jelas dan operasional & 0.598 & 0.195 & 0,000 & Valid \\
\hline 5 & Pimpinan memberikan sanksi atas pelanggaran yang dilakukan & 0.531 & 0.195 & 0,000 & Valid \\
\hline 6 & Pimpinan bersikap tegas dalam setiap pengambilan keputusan & 0.510 & 0.195 & 0,000 & Valid \\
\hline 7 & Pimpinan memiliki kewibawaan & 0.472 & 0.195 & 0,000 & Valid \\
\hline 8 & Pimpinan memiliki kreatifitas tinggi dan inovatif & 0.474 & 0.195 & 0,000 & Valid \\
\hline 9 & $\begin{array}{l}\text { Pimpinan memberikan kesempatan kepada pegawai mengambil } \\
\text { keputusan berkaitan dengan penyelesaian tugas yang diberikan }\end{array}$ & 0.324 & 0.195 & 0,022 & \multirow{2}{*}{ Valid } \\
\hline 10 & $\begin{array}{l}\text { Standar pekerjaan yang diberikan oleh pimpinan bersifat terukur } \\
\text { dan jelas }\end{array}$ & 0.343 & 0.195 & 0,000 & Valid \\
\hline
\end{tabular}

Sumber: Hasil penelitian, 2020 dan Olahan SPSS

Dari hasil perhitungan validitas variabel Kepemimpinan, semua butir pernyataan yang dinyatakan valid, karena nilai $\mathrm{r}_{-}{ }_{\text {hitung }}>\mathrm{r}^{-}{ }_{\text {tabel }}$ sehingga dapat digunakan dalam penelitian selanjutnya.

\section{Uji Valisitas Variabel Budaya Organisasi $\left(\mathrm{X}_{2}\right)$}

Menggunakan konsep Robbins dan Timoty (2008:256), instrumen yang mengukur variabel Budaya Organisasi $\left(\mathrm{X}_{2}\right)$ berdasarkan 5 dimensi, yakni; 1) Kesadaran diri, 2) Keagresifan, 3) Kepribadian, 4). Performa dan 5) Orientasi tim.

Hasil uji validitas variabel ini dinyatakan berikut ini:

Tabel 3. Uji Validitas Instrumen untuk Variabel Budaya Organisasi $\left(\mathrm{X}_{2}\right)$

\begin{tabular}{|c|l|c|c|c|c|}
\hline Butir & \multicolumn{1}{|c|}{ Pernyataan } & r-hitung & r-tabel & Sig & Keputusan \\
\hline 1 & Pegawai menyelesaikan tugas tepat waktu dengan metodenya sendiri & -0.057 & 0.195 & 0,565 & TidakValid \\
\hline 2 & Pegawai berusaha mengeluarkan pendapat jika organisasi terkena masalah & 0.436 & 0.195 & 0,000 & Valid \\
\hline 3 & Tempat bekerja mengadakan pelatihan kerja untuk pegawai & 0.348 & 0.195 & 0,011 & Valid \\
\hline 4 & Tempat bekerja mendorong pegawai untuk teliti dalam bekerja & 0.656 & 0.195 & 0,000 & Valid \\
\hline 5 & Atasan memperhatikan kepentingan pegawai yang mengalami kesulitan & 0.640 & 0.195 & 0,000 & Valid \\
\hline
\end{tabular}




\begin{tabular}{|l|l|c|c|c|c|}
\hline 6 & Komunikasi atasan dengan atasan selalu terjalin dengan baik & 0.647 & 0.195 & 0,000 & Valid \\
\hline 7 & Komunikasi atasan dengan bawahan selalu terjalin dengan baik & 0.742 & 0.195 & 0,000 & Valid \\
\hline 8 & Pimpinan memberikan motivasi dalam menjalankan tugas pegawai & 0.481 & 0.195 & 0,000 & Valid \\
\hline
\end{tabular}

Sumber: Hasil penelitian, 2020 dan Olahan SPSS

Dari hasil perhitungan validitas variabel Budaya organisasi terbukti terdapat saah satu yang tidak valid, yakni butir-1, sehingga yang digunakan hanya 7 butir untuk penelitian selanjutnya.

\section{Variabel Motivasi kerja $\left(X_{3}\right)$}

Berdasarkan Hasibuan (2013:143), instrumen yang mengukur variabel ini dirancang dari 3 dimensi tentang kebutuhan, yakni: 1) Kebutuhan akan prestasi, 2) Kebutuhan akan afiliasi, dan 3) Kebutuhan akan kekuasaan, yang hasil uji validitasnya dinyatakan sebagai berikut:

Tabel 4. Uji Validitas Instrumen untuk Variabel Motivasi $\left(\mathrm{X}_{3}\right)$

\begin{tabular}{|c|l|c|c|c|c|}
\hline Butir & \multicolumn{1}{|c|}{ Pernyataan } & r-hitung & r-tabel & Sig & Keputusan \\
\hline 1 & Saya bekerja dengan giat agar diberikan promosi jabatan & 0.702 & 0.195 & 0,000 & Valid \\
\hline 2 & Saya bekerja dengan giat untuk mendapat perhatian pemimpin & 0.460 & 0.195 & 0,000 & Valid \\
\hline 3 & Saya bekerja melebihi target agar mendapat bonus & 0.618 & 0.195 & 0,000 & Valid \\
\hline 4 & Saya bekerja dengan giat agar memperoleh insentif dari kantor & 0.312 & 0.195 & 0,001 & Valid \\
\hline 5 & Gaji yang diberikan kantor cukup memenuhi kebutuhan saya & 0.469 & 0.195 & 0,000 & Valid \\
\hline 6 & Saya bekerja untuk memenuhi kebutuhan saya & 0.455 & 0.195 & 0,000 & Valid \\
\hline 7 & Pekerjaan saya saat ini adalah impian saya & 0.453 & 0.195 & 0,000 & Valid \\
\hline 8 & Pekerjaan saya saat ini membuat saya senang & 0.410 & 0.195 & 0,000 & Valid \\
\hline 9 & Saya selalu mengerjakan tugas dengan tepat waktu & 0.387 & 0.195 & 0,000 & Valid \\
\hline 10 & Saya selalu menyelesaikan tugas dengan penuh tanggung jawab & 0.702 & 0.195 & 0,000 & Valid \\
\hline
\end{tabular}

Sumber: Hasil penelitian, 2020 dan Olahan SPSS

Dari hasil perhitungan validitas variabel motivasi kerja ini, semua butir pernyataan dinyatakan valid untuk penelitian selanjutnya.

\section{Variabel Kinerja Pegawai (Y)}

Konsep variabel tentang kinerja mengutip dari Wibowo (2011:70), menggunakan instrumen pengukurnya yakni kuantitas, kualitas dan waktu. Hasil pengkuran validitas isi indikator tersebut, diperoleh:

Tabel 5. Uji Validitas Instrumen untuk Variabel Kinerja (Y)

\begin{tabular}{|c|l|c|c|c|c|}
\hline Butir & Pernyataan & r-hitung & r-tabel & Sig & Keputusan \\
\hline 1 & Hasil kerja pegawai sesuai dengan standar yang ditetapkan instansi & 0.329 & 0.195 & 0,001 & Valid \\
\hline 2 & Pegawai bekerja sesuai dengan standar yang diinginkan instansi & 0.162 & 0.195 & 0,101 & TidakValid \\
\hline 3 & Pegawai mampu menyelesaikan pekerjaan sesuai target & 0.423 & 0.195 & 0,000 & Valid \\
\hline 4 & Pekerjaan mencapai target yang ditetapkan & 0.451 & 0.195 & 0,000 & Valid \\
\hline 5 & Menyelesaikan pekerjan dengan cepat & 0.510 & 0.195 & 0,000 & Valid \\
\hline 6 & Menyelesaikan pekerjaan secara yang lebih praktis dan rapi & 0.500 & 0.195 & 0,000 & Valid \\
\hline 7 & Kualitas hasil kerja pegawai sesuai dengan standar instansi & 0.523 & 0.195 & 0,000 & Valid \\
\hline 8 & Kuantitas hasil kerja melebihi pegawai lain & 0.696 & 0.195 & 0,000 & Valid \\
\hline
\end{tabular}

Sumber: Hasil olhan SPSS, 2020

Dari hasil perhitungan validitas variabel kinerja pegawai, terdapat butir ke-2 yang tidak valid, sedangkan lainnya valid pada taraf uji 5\% sehingga hanya 7 butir pernyataan dapat digunakan untuk penelitian selanjutnya.

\section{c. Hasil analisis Deskriptif}

Berdasarkan hasil kuesioner yang telah teruji validitas dan reliabilitasnya diperoleh informasi berikut.

Tabel 6. Deskripsi Penilaian Pegawai tentang Variabel Penelitian

\begin{tabular}{|c|c|c|c|c|c|c|}
\hline \multirow[t]{2}{*}{ Variabel } & \multicolumn{5}{|c|}{$\begin{array}{c}\text { Jumlah \& } \\
\text { Persentase Jawaban Responden }\end{array}$} & \multirow{2}{*}{$\begin{array}{c}\text { Skor } \\
\text { Persentase } \\
\text { Pencapaian }\end{array}$} \\
\hline & STS & TS & KS & S & SS & \\
\hline \multirow{2}{*}{ - Kepemimpinan : 10 pernyataan } & 1 & 24 & 490 & 419 & 106 & \multirow{2}{*}{$71,60 \%$} \\
\hline & 0.10 & 2.31 & 47.12 & 40.29 & 10.19 & \\
\hline \multirow{2}{*}{ - $\quad$ Budaya organisasi : 8 pernyataan } & 1 & 22 & 525 & 258 & 26 & \multirow{2}{*}{$53,46 \%$} \\
\hline & 0.12 & 2.64 & 63.10 & 31.01 & 3.13 & \\
\hline \multirow{2}{*}{ - Motivasi : 10 pernyataan } & 57 & 346 & 545 & 85 & 7 & \multirow{2}{*}{$50,87 \%$} \\
\hline & 5.48 & 33.27 & 52.40 & 8.17 & 0.67 & \\
\hline \multirow{2}{*}{ - $\quad$ Kinerja : 8 pernyataan } & 15 & 72 & 617 & 124 & 4 & \multirow{2}{*}{$48,0 \%$} \\
\hline & 1.80 & 8.65 & 74.16 & 14.90 & 0.48 & \\
\hline
\end{tabular}

Sumber : Hasil Peneltian, 2020 
Penelitian dengan angket bersifat tertutup dengan 5 pilihan jawaban, dari pilihan sangat tidak setuju sampai sangat setuju atas suatu pernyataan. Hasil survey, diperoleh informasi deskripsi berikut:

-Variabel Kepemimpinan;

Persepsi responden (pegawai) mengungkapkan bahwa sekitar 50 persen ssetuju dan sangat setuju, bahwa pimpinan sudah menjalankan fungsi dan wewenangnya secara baik di kantor UPT Dinas Pendidikan, Pemuda dan Olahraga Kabupaten Bireuen, namun cukup besar yang menyatakan kurang setuju $(47,12$ persen). Secara umum persentase pencapaian aspek kepemimpinan yang diharapkan pegawai mencapai $71,60 \%$. Dan hasil ini menunjukkan belum cukup baik.

-Variabel Budaya Organisasi;

Persepsi responden (pegawai) mengungkapkan bahwa hanya 34 persen sangat setuju dan setuju, bahwa budaya organisasi yang berlaku telah mendukung kinerja pegawai UPT Dinas Pendidikan, Pemuda dan Olahraga Kabupaten Bireuen. Terdapat 63,10\% tanggapan pegawai menyatakan kurang. Sedangkan skor pencapaian faktor budaya organisasi kaitan dengan peningkatan kinerja pegawai baru mencapai $53,46 \%$.

-Variabel Motivasi kerja pegawai;

Berkaitan dengan penlaian motivasi kerja pegawai, yang terkait dengan tersedianya kebutuhan pegawai, menurut persepsi pegawai, bahwa terdapat dibawah 10 persen yang sangat setuju dan setuju. Terlihat cukup besar, yakni 52,40 \% menyatakan kurang dari harapan. Sehingga persentase pencapaian aspek motivasi pegawai dalam menigktakan kinerja masih rendah yakni 50,87\%.

-Variabel Kinerja;

Tingkat kinerja juga belum menggimrakan, skor pencapaiannya baru 48 persen dari harapan. Hanya 15 persen pegawai yang kinerja tinggi.

\title{
d. Hasil Analisis Jalur
}

Dengan pendekatan analisis jalur, yakni kombinasi regresi variabel bebas terhadap variabel tak bebas (Kinerja) dan adanya hubungan kausalitas antar variabel bebas $\left(\mathrm{r}_{\mathrm{x} i, \mathrm{j}}\right)$, dinyatakan dalam gambar 1 berikut:

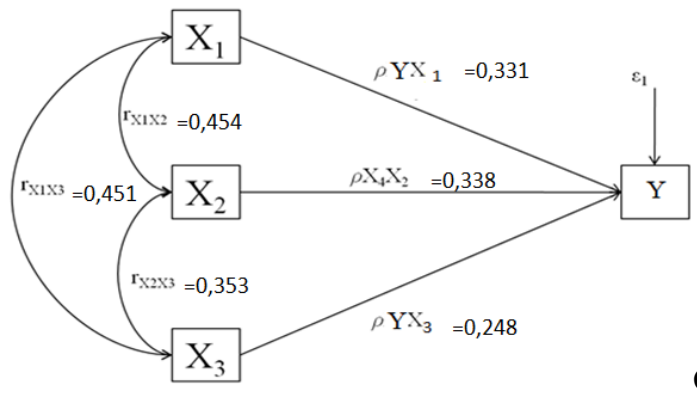

\author{
Keterangan : \\ $\mathrm{Y}=$ Kinerja \\ $\mathrm{X} 1=$ Kepemimpinan \\ $\mathrm{X} 2$ = Budaya Organisasi \\ $\mathrm{X} 3=$ Motivasi
}

Gambar 1 Diagram Jalur Penelitian

\section{e. Uji Model}

Sebagaimana tujuan dari penelitian ini, untuk mengetahui pengaruh variabel eksogen (Kepemimpinan, Budaya Organisasi dan Motivasi pegawai) terhadap Kinerja pegawai di lingkungan UPTD Pendidikan Pemuda dan Olahraga Kabupaten Bireuen. Maka untuk itu dilakukan pengujian hipotesis berikut ini;

Hipotesis 1: Kepemimpinan berpengaruh terhadap Kinerja

Hasil ujiu menunjukkan harga $t_{\text {hitung }}$ sebesar 3,992 yang lebih besar dari $t$-tabel $=1,96$, dan nilai ini signifikans pada taraf uji 5\%. Sehingga Ho ditolak dan Ha diterima artinya koefisien jalur Kepemimpinan $\left(\mathrm{X}_{1}\right)$ berpengaruh terhadap Kinerja pegawai pada UPTD Pendidikan Pemuda dan Olahraga Kabupaten Bireuen.

Hipotesis 2: Budaya organisasi berpengaruh terhadap Kinerja

Hasil uji menyatakan $t_{\text {hitung }}>t_{\text {tabel }}(4,270>1,96)$, dan nilai ini juga signifikansi dari hasil olahan data pada taraf uji 5\%. Sehingga Ho ditolak dan Ha diterima artinya koefisien jalur variabel Budaya organisasi $\left(\mathrm{X}_{2}\right)$ terhadap Kinerja dalam model signifikan. Dengan demikian dapat dinyatakan bahwa terdapat pengaruh secara signifikan Budaya organisasi $\left(\mathrm{X}_{2}\right)$ terhadap Kinerja pegawai pada UPTD Pendidikan Pemuda dan Olahraga Kabupaten Bireuen.

Hipotesis 3: Motivasi berpengaruh terhadap Kinerja

Hasil uji menunjukkan harga $t_{\text {hitung }}$ sebesar 3,145. Dengan demikian $t_{\text {hitung }}>t_{\text {tabel }}(3,145>1,96)$. Sehingga Ha diterima artinya koefisien jalur variabel motivasi kerja dalam model, dinyatakan signifikans. Sehingga 
variabel Motivasi kerja $\left(\mathrm{X}_{3}\right)$ berpengaruh terhadap Kinerja pegawai pada UPTD Pendidikan Pemuda dan Olahraga Kabupaten Bireuen.

\section{f. Hasil Analisis Pengaruh variabel dan Pembahasan}

\section{1). Pengaruh Variabel Kepemimpinan terhadap Kinerja}

\section{Pengaruh langsung:}

Besarnya pengaruh langsung variabel Kepemimpinan dengaan koefisien jalur $\left(\rho_{\mathrm{yx} 1}=0,331\right)$, adalah: $(0,331)^{2} \times 100 \%=10,96 \%$.

\section{Pengaruh Tidak langsung}

Besarnya pengaruh tak langsung Kepemimpinan di hitung sebagai berikut:

- Pengaruh Kepemimpinan melalui Budaya organisasi, adalah $(0,331)(0,454)(0,338)$ x $100 \%=5,08 \%$

- Pengaruh Kepemimpinan melalui Motivasi, adalah $=(0,331)(0,451)(0,248) \times 100 \%=3,70 \%$.

\section{Pengaruh Total Kepemimpinan terhadap Kinerja pegawai}

Berdasarkan pengaruh langsung dan tidak langsung, maka dapat dihitung besarnya pengaruh total Kepemimpinan terhadap Kinerja pegawai, yakni : 10,96\%+5,08\%+3,70\%=19,74 persen.

\section{2). Pengaruh Variabel Budaya Organisasi terhadap Kinerja}

\section{Pengaruh langsung:}

Besarnya pengaruh langsung Budaya organisasi dengan koefisien jalur $\left(\rho_{\mathrm{yx} 2}=0,338\right)$, Sehingga besarnya pengaruh langsung ini adalah: $(0,338)^{2} \times 100 \%=10,42 \%$.

\section{Pengaruh Tidak langsung}

- Pengaruh Budaya organisasi melalui Kepemimpinan, adalah $(0,338)(0,454)(0,331) \times 100 \%=5,08 \%$

- Pengaruh Budaya organisasi melalui motivasi kerja, adalah $(0,338)(0,353)(0,248) \times 100 \%=2,96 \%$

\section{Pengaruh Total Budaya organisasi terhadap Kinerja}

Berdasarkan pengaruh langsung dan tidak langsung, maka dapat dihitung besarnya pengaruh total Budaya organisasi terhadap Kinerja pegawai, yakni 10,42 \%+5,08\% + 2,96\%=19,46\% .

\section{3). Pengaruh Variabel Motivasi terhadap Kinerja Pegawai}

\section{Pengaruh langsung:}

Besarnya pengaruh langsung Motivasi kerja dengan koefisien jalur $\left(\rho_{\mathrm{yx} 3}=0,248\right)$, Sehingga besarnya pengaruh langsung ini adalah: $(0,248)^{2} \times 100 \%=6,15 \%$.

\section{Pengaruh Tidak langsung}

- Pengaruh Motivasi melalui Kepemimpinan, adalah $=(0,248)(0,451)(0,331) \times 100 \%=3,70 \%$

- Pengaruh Motivasi melalui Budaya organisasi, adalah $=(0,248)(0,353)(0,338) \times 100 \%=2,96 \%$

\section{Pengaruh Total Motivasi kerjar terhadap Kinerja pegawai}

Berdasarkan pengaruh langsung dan tidak langsung, maka dapat dihitung besarnya pengaruh total motivasi kerja terhadap Kinerja pegawai, yakni: $6,15 \%+3,70 \%+2,96 \%$ atau $12,81 \%$.

4). Pengaruh Variabel Kepemimpinan, Budaya organisasi, dan Motivasi kerja terhadap Kinerja Pegawai UPTD Pendidikan Pemuda dan Olahraga Kabupaten Bireuen

Berdasarkan pengujian model jalur di atas maka dapat dituliskan persamaan untuk model jalur adalah sebagai berikut: $\mathrm{Y}=0,331 \mathrm{X}_{1}+0,338 \mathrm{X}_{2}+0,248 \mathrm{X}_{3}$

$$
\text { ( } Y=\text { Kinerja pegawai, } X 1=\text { Kepemimpinan, } X 2=\text { Budaya organisasi, } X 3=\text { Motivasi })
$$

Nilai koefisien jalur variabel Kepemimpinan bernilai positif $(0,331)$ artinya apabila pimpinan yang dipersepsikan dan diraskan pegawai, membawa kerja pegawai dengan baik akan dapat mendukung kinerja pegawai dengan rata-rata kenaikan $33,1 \%$.

Juga adanya budaya organisasi yang dijalankan sesuai kebiasaan, peraturan dan norma ataupun nialinilai dalam budaya kerja yang kondusif dan mendukung dapat meningkatkan Kinerja pegawai UPT Dinas Pendidikan Pemuda dan Olahraga Kabupaten Bireuen, dengan koefisien kenaikannya bernilai positif $(0,338)$ artinya rata-rata kenaikannya adalah $33,8 \%$. 
Koefisien jalur Motivasi pegawai bernilai positif $(0,248)$ artinya apabila pegawai termotivasi terus untuk berprestasi akan menaikkan rata-rata 24,6 persen dari kinerja pegawai, dengan rata-rata kenaikan $24,8 \%$.

Selain menguji koefisien regresi, penelitian ini juga menguji koefisien korelasi (R) dan koefisien determinasi $\left(\mathrm{R}^{2}\right)$. Korelasi determinasi $\left(\mathrm{R}^{2}\right)$ mengukur seberapa jauh kemampuan variabel-variabel independen dalam menjelaskan variasi variabel dependen (Ghozali, 2012).

Maka analisis koefisien korelasi dan determinasi variabel bebas atau dalam hal ini disebut variable eksogen $(\mathrm{X})$ dengan variabel endogen( $\mathrm{Y})$ yang dapat dilihat dari tabel berikut:

Tabel 7. Koeisien Korelasi Simultan

\begin{tabular}{|c|c|c|c|}
\hline $\mathrm{R}$ & R Square & Adjusted R Square & Std. Error of Estimate \\
\hline 0.721 & 0.520 & 0.506 & 2.07903 \\
\hline
\end{tabular}

Hasil analisis koefisien korelasi menjelaskan hubungan antara variabel Kepemimpinan, Budaya organisasi dan motivasi terhadap variabel Kinerja, memiliki keeratan yang tinggi, dan berhubungan secara linier, dengan derajat hubungannya sebesar 0,721 .

Nilai koefisien determinasi sebesar 0,520 menjelaskan bahwa kontribusi faktor Kepemimpinan, Budaya organisasi dan motivasi terhadap kinerja pegawai UPTD Pendidikan Pemuda dan Olahraga Kabupaten Bireuen sebesar $52 \%$.

\section{Simpulan (Conclusion)}

\section{1). Hasil Penelitian Deskriptif}

a. Berdasarkan respon dari pegawai di kantor UPTD Pendidikan Pemuda dan Olahraga Kabupaten Bireuen, bahwa persentase pencapaian aspek kepemimpinan yang diharapkan pegawai baru mencapai 71,60\%. Dan hasil ini menunjukkan belum cukup maksimal.

b. Aspek budaya organisasi belum berjalan optimal, skor pencapaian faktor budaya organisasi dalam kaitan dengan peningkatan kinerja pegawai baru mencapai 53,46 \% dari kondisi idealnya.

c. Sedangkan tingkat motivasi kerja pegawai masih rendah, hanya 10 persen yang motivasinya tinggi diatas rata-rata. Secara umum pencapaian motivasi kerja sesuai dengan harapan baru mencapai $50,87 \%$.

\section{2). Hasil Penelitian Kuantitatif dengan Analisis Jalur}

Berdasarkan analisis secara kuantitatif, menggunakan pendekatan analisis jalur, diperoleh hasil sebagai berikut:

a) Terdapat Pengaruh yang signifikans faktor kepemimpinan terhadap kinerja pegawai. Secara statistik, ditemukan pengaruh kepemimpinan dari model yang dianalisis sebesar 19,74 persen terhadap kinerja pegawai UPTD Pendidikan Pemuda dan Olahraga Kabupaten Bireuen.

b) Terbukti adanya pengaruh budaya organisasi terhadap kinerja pegawai. Secara statistik, ditemukan pengaruh Budaya organisasi dari model yang dianalisis sebesar 19,46 persen terhadap kinerja pegawai UPTD Pendidikan Pemuda dan Olahraga Kabupaten Bireuen.

c) Ditemukan adanya pengaruh yang signifikans faktor motivasi kerja pegawai sebesar 12,81 persen terhadap kinerja pegawai UPTD Pendidikan Pemuda dan Olahraga Kabupaten Bireuen.

d) Berdasarkan nilai koefisien determinasi sebesar 0,721 menjelaskan hubungan antara variabel eksogen (Kepemimpinan, Budaya organisasi dan motivasi) terhadap variabel endogen (Kinerja), memiliki keeratan yang tinggi, dan berhubungan secara linier, dengan derajat hubungannya sebesar 0,721.

e) Nilai koefisien determinasi sebesar 0,520 menjelaskan bahwa kontribusi faktor Kepemimpinan, Budaya organisasi dan motivasi terhadap kinerja pegawai UPTD Pendidikan Pemuda dan Olahraga Kabupaten Bireuen sebesar $52 \%$. Sementara sisanya dari peran variabel yang tidak diteliti sebesar $48 \%$. Hal ini menunjukkan bahwa terdapat faktor-faktor lain yang dapat mempengaruhi variabel kinerja pegawai, seperti Iklim organisasi, faktor pengembangan karier, adanya Pendidikan dan pelatihan (diklat), dan lain-lain. 


\section{DAFTAR PUSTAKA (References)}

1) Anoraga, Pandji, 2012, Manajemen Bisnis, Rineka Cipta, Jakarta.

2) Anwar Prabu Mangkunegara. 2011. Manajemen Sumber Daya Manusia Perusahaan. PT. Remaja Rosdakarya. Bandung.

3) Diana Angelica (2008

4) Ghozali, Imam. 2012. Aplikasi Analisis Multivariate dengan Program IBM SPSS. Yogyakarta: Universitas Diponegoro

5) Hasibuan, M. 2013. Manajemen Sumber Daya Manusia. Jakarta: Bumi Aksara.

6) Marwan Hamid, Ibrahim Sufi, Win Konadi, dan Yusrizal Akmal, 2019. Analisis Jalur Dan Aplikasi Spss Versi 25, Edisi Pertama Sefa Bumi Persada, Medan.

7) Moeheriono. 2009. Pengukuran Kinerja Berbasis Kompetensi. Bogor: Ghalia Indonesia.

8) Robbins, S. 2015. Perilaku Organisasi. Jakarta: Salemba Empat.

9) Robbins, S., \& Coulter, M. 2010. Manajemen. Jakarta: Erlangga.

10) Robert, L. Mathis \& John H.Jakson. 2006. Human Resource Management. Terj Diana Angelica. Manajemen Sumber Daya Manusia. Jakarta: Salemba Empat.

11) Sarwono, Jonathan. 2011, Metodelogi Penelitian Kuantitatif Dan Kualitatif, Jogjakarta: Graha Ilmu.

12) Siagian, Sondang P.2008. Teoridan Praktek Kepemimpinan. Jakarta.Rineka Cipta.

13) Sutrisno Edy, 2014. Manajemen Sumber Daya Manusia. Cetak Ke Enam. Pranada Media Group. Jakarta.

14) Stephen P. Robbins and Timothy A. Judge. 2008. Perilaku Organisasi Edisi 12 Buku 1. Terjemahan: Diana Angelica, Ria Cahyani dan Abdul Rosyid. Jakarta: Salemba Empat.

15) Thoha, Chabib. 2011. Teknik Evaluasi Pendidikan. Jakarta. Rajawali Press.

16) Winardi. 2006. Manajemen Perkantoran dan Pengawasan. Bandung. Alfabeta.

17) Wijayanti, Irine Diana Sari. 2008. Manajemen. Editor: Mitra Cendikia. Yogyakarta.

18) Wibowo. 2006. Manajemen Perubahan. Jakarta : Raja Grafindo Persada. 